\title{
Arctic Policy, Fisheries Management, Traditional Knowledge, and Protection of Indigenous Peoples' Languages
}

Arctic Review on Law and Politics aims at presenting such topics related to the Circumpolar Northern societies as policy and governance issues, resource management, and matters concerning indigenous peoples. In this issue, we have the pleasure of offering four peer-reviewed articles analyzing policy approaches, fisheries management, incorporation of traditional knowledge, and realizing legal obligations to protect indigenous peoples' languages; all with a focus on the Arctic. Consequently, this issue has a fine balance of articles, representing the kind of subjects we like to present in Arctic Review on Law and Politics.

Kamrul Hossain explores EU engagement in the Arctic. He discusses whether the policy responses from the eight Arctic states forming the Arctic Council recognize the European Union as a legitimate stakeholder. The article concludes that although the Arctic states determine the region's governance approach, they include the EU in a general partnership role with regard to the common goals of knowledge-based responsible governance and sustainable development of the Arctic.

Referring to the European Maritime Affairs and Fisheries Commissioner's statement "Getting it right," Peter Orebech analyzes the legislative and legal perspectives of the new but still intermediate fisheries management regulation of 2013 . His concern is that the reported sweeping platform for a new Common European Union fishery policy, as announced, will not succeed. While the draft law's ambitions and proposals herald a new era, the final text of the 2013 regulation takes a U-turn and returns more or less back to basics. Thus, the EU will still have to cope with its self-declared "five structural failings."

Einar Eypórsson and Alma Elizabeth Thuestad elaborate on how indigenous peoples' traditional knowledge can be incorporated in environmental impact assessment, particularly in Sámi areas of Norway. Referring to the obligation in the 2009 Norwegian Nature Diversity Act to consider traditional knowledge in planning, resource, and land management, they find that experiences from reviews for the Finnmark Commission and impact assessments concerning Sámi land and resource use may represent a step toward incorporating traditional knowledge in Norwegian planning processes. However, the approach to documentation, methodology, and ethics in this field is open for debate.

Focusing on the Nenets Autonomous Okrug of the Russian High North, Ekaterina Zmyvalova examines how legal commitments concerning indigenous children's right 
to learn their mother tongue are realized in Russia. In the area in focus, the number of indigenous people who speak their native tongue has decreased threefold from 2002 to 2010. The author addresses a wide range of factors impacting the language situation, inter alia the political situation, the learning environment, and the inadequate implementation of international law protecting indigenous languages.

In August 2015, the Uncultivated Land Tribunal for Finnmark, a special court established among other reasons due to Norway's commitment to the Sámi, issued its first judgment. The outcome of the judgment is perhaps less remarkable, however, than other conditions - such as the lack of budgetary funding for the court. The editorin-chief has contributed a short elaboration over the outcome of the first year of the tribunal at the end of this issue. There readers will also find an attention-grabbing book review by Terry Fenge.

We are happy to present all these interesting explorations in law in the Arctic. Pleasant reading.

Oyvind Ravna

Editor-in-Chief 